\title{
Methodical aspects of quantitative elemental analysis of organic compounds using automated CHNS-analyzers
}

\author{
C Igor M. Fitsev, ${ }^{1{ }^{+}}$Maria Yu. Vakhitova, ${ }^{1}$ Vasily M. Babaev, ${ }^{1}$ \\ Evgenia I. Fitseva, ${ }^{2}$ Ksenia S. Bulygina, $^{1}$ and Ildar Kh. Rizvanov ${ }^{1}$ \\ ${ }^{1}$ Arbuzov Institute of Organic and Physical Chemistry. FRC Kazan Scientific Center. Russian Academy \\ of Sciences. Arbuzova St., 8. Kazan, 420088.Russia.E-mail:igor.fitsev@iopc.ru \\ ${ }^{2}$ D. Mendeleev University of Chemical Technology of Russia. Faculty of Information Technology \\ and Management. Department of Information Systems and Technologies. \\ Miusskaya Sq, 9. Moscow A-47, 125047. Russia.
}

\section{*Supervising author; ${ }^{+}$Corresponding author}

Keywords: quantitative elemental analysis of organic compounds, gas chromatography, thermal conductivity detector, the research of materials, substances and products.

\begin{abstract}
In this article the methodical aspects of quantitative elemental analysis of organic compounds on the automatic CHNS-analyzers, combining the method of Dumas-Pregl and gas chromatographic separation of analytic forms elements $\left(\mathrm{N}_{2}, \mathrm{CO}_{2}, \mathrm{H}_{2} \mathrm{O}, \mathrm{SO}_{2}\right)$ recorded by the thermal conductivity detector are explored. Also there are shown methods of calibration of the thermal conductivity detector, including the traditional way that uses one standard sample and the way that uses three standard samples with different quantitative content determined elements. Besides, attached the methodical approach, which is used in quantitative elemental analysis of organic compounds and their mixtures on the automatic CHNS-analyzers made on local and abroad plants, is based on operative control of calibration characteristics that we get from the thermal conductivity detector (characteristics and results of a standard sample of known composition before and after elemental analysis of unknown compound).
\end{abstract}

\section{References}

[1] N.E. Gelman, E.A. Terentyeva, G.M. Shanina, L.M. Kiparenko, V. Rezl. Methods of quantitative organic elemental microanalysis. Monograph. Chemistry, Moscow. 1987. 295p. (russian)

[2] L. Mazor. Methods of organic analysis: Per from English. Monograph. Mir, Moscow. 1986. 584p. (russian)

[3] I.M. Fitsev, V.K. Blokhin, G.K. Budnikov. Chromatographic techniques in forensic chemical examinations. J. Anal. Chem. 2004. Vol.159. No 12. P. 1171-1180. (russian)

[4] I.A. Revel'skii, E.N. Kapinus, M.V. Fedoseeva, G.N. Gil'deeva, V.V. Kosenko, A.I. Revel'skii. Determination of the main component in high-purity organic substances: Current status and prospects. $J$. Anal. Chem. 2009. Vol.64. No.9. P.926-929. (russian)

[5] V.P. Miroshina, E.M. Dubina, T.L. Kusova, G.S. Vasilyeva. Experience of using the analyzer 1106 by Carlo Erba (Italy) for automatic C, H, N, S, O - analysis of organic substances. J. Anal. Chem. 1992. Vol.47. No.6. P.1112-1117. (russian)

[6] V.P. Fadeeva, V.D. Tikhova, O.N. Nikulicheva. Elemental analysis of organic compounds with the use of automated CHNS analyzers. J. Anal. Chem. 2008. Vol.63. No.11. P.1094-1106. (russian)

[7] V.P. Fadeeva, V.D. Tikhova, Y.M. Deryabina, O.N. Nikulicheva. Determination of organogenic elements in the composition of functional compounds and materials. J. Struct. Chem. 2014. Vol.55. No.5. P.972979. (russian)

[8] E.A. Zauer. Modern automatic CHNS/O/X organic compound analyzers. Analytics and Control. 2018. Vol.22. No.1. P.6-19. (russian)

[9] GOST R (Russian National Standard) 8.736-2011. State system for ensuring the uniformity of measurements. Multiple direct measurements. Methods of measurement results processing. Main principles. Moscow: Standartinform. 2013. 24p. (russian)

[10] GOST (State Standard) 34100.1- 2017. Uncertainty of measurement. Part 1. Introduction to guides on the expression of uncertainty in measurement. Moscow: Standartinform. 2017. 28p. (russian) 